\title{
Cigarette Smoking in Patients with
}

\section{Schizophrenia in Turkey:}

\section{Relationships to Psychopathology,}

\section{Socio-Demographic and Clinical}

\section{Characteristics}

\section{ABSTRACT}

Cigarette smoking in patients with schizophrenia in Turkey: relationships to psychopathology, socio-demographic and clinical characteristics

Objective: In individuals with schizophrenia, the prevalence of cigarette smoking is significantly higher than that of the general population. This appears to be associated with specific psychosocial and clinical characteristics. However, there is limited data regarding the relationship between smoking and psychopathology, insight, impulsivity, suicidality, hopelessness and depression in patients with schizophrenia. In this regard, the purpose of this study was to examine the relationship between these characteristics and smoking in patients with schizophrenia in Turkey.

Method: In this cross-sectional study, 133 outpatients with DSM-IV diagnosis of schizophrenia were recruited and independently interviewed for nicotine dependency with tobacco use. Scale for Assessment of Negative and Positive Symptoms (SANS and SAPS), Calgary Depression Scale for Schizophrenia (CDSS), Beck Hopelessness Scale (BHS), Barrat Impulsivity Scale (BIS), The Yale-Brown Obsessive-Compulsive Scale (YBOCS), Beck Cognitive Insight Scale, Scale of Unawareness of Mental Disorder (SUMD) were used to evaluate related psychopathologic variables.

Results: The results revealed that smokers with schizophrenia had higher rates of hospitalization, lifetime suicide attempts, more severe psychopathology, higher impulsivity and hopelessness scores than nonsmokers with schizophrenia. In addition, another important result was that smokers with schizophrenia have higher unemployment rates.

Conclusion: From this study, we may gain new insights into the role of cigarette smoking in patients of schizophrenia in Turkey. Our findings suggest that cigarette smoking is associated with not only severe psychopathology but also with impulsivity and hopelessness which are related to suicidality, in patients with schizophrenia. This relationship between suicidality, impulsivity and hopelessness may be of clinical importance for patients with schizophrenia.

Key words: Schizophrenia, smoking, hopelessness, suicide, psychopathology

\section{ÖZET}

Türkiye'de şizofreni hastalarında sigara kullanımının psikopatolojik, sosyodemografik ve klinik özelliklerle ilişkisi

Amaç: Şizofreni hastalarında sigara kullanımı yaygınlığı, genel toplumdakinden anlamlı biçimde yüksektir ve bu durum bazı psikososyal ve klinik özelliklerle ilişkili görünmektedir. Bununla birlikte, şizofrenide sigara kullanımı ile psikopatoloji, içgörü, intihar, umutsuzluk ve depresyon arasındaki ilişki hakkında sınırlı sayıda çalışma bulunmaktadır. Çalışmamııı amacı, Türkiye'de sigara kullanan şizofreni hastalarında sigara kullanımının bu klinik değişkenlerle ilişkisini araştırmaktır.

Yöntem: Bu kesitsel nitelikteki çalıșmaya, DSM-IV'e göre şizofreni tanısı almış, ayakta tedavi gören 133 hasta dahil edildi ve nikotin bağımlılı̆ını değerlendirmek amacıyla her biriyle ayrı ayrı görüşüldü. Hastaların pozitif ve negatif belirtileri Pozitif Belirtileri Değerlendirme Ölçeği (PBDÖ) ve Negatif Belirtileri Değerlendirme Ölçeği (NBDÖ), depresyonun derecesi Calgary Şizofrenide Depresyon Ölçeği (CŞDÖ), umutsuzluk düzeyleri Beck Umutsuzluk Ölçeği (BUÖ), dürtüsellik düzeyleri Barrat Dürtüsellik Ölçeği (BDÖ), obsesif-kompulsif belirtileri Yale Brown Obsesyon Kompulsiyon Ölçeği (Y-BOKÖ), içgörüleri Beck Bilişsel Iç̧ö̈rü (BBiÖ) ve Akıl Hastalığına içgörüsüzlük Ölçeği (AHiÖ) ile değerlendirildi.

Bulgular: Bulgularımız, sigara kullanan șizofrenili olgularda yatarak tedavi görme, intihar girișiminde bulunma oranlarının daha yüksek olduğuna, mevcut psikopatolojilerinin daha ciddi olduğuna, umutsuzluk ve dürtüsellik düzeylerinin de daha yüksek olduğuna işaret etmektedir. Ayrıca, sigara kullanan hastalarda işsizlik oranının daha yüksek olması da dikkati çekmekteydi.

Sonuç: Çalışmamız Türkiye'de şizofreni hastalarında sigara kullanımının rolüile ilgili yeni bakış açıları kazandırabilir. Bulgularımız, sigara kullanımının şizofrenili olgularda daha ciddi psikopatolojinin yanı sıra, intihar eğilimi, umutsuzluk ve dürtüsellikle de ilișki içinde olduğuna işaret etmektedir. Şizofrenili olgularda sigara içiminin intihar, umutsuzluk ve dürtüsellikle olan ilişkisi, bu hasta grubunun tedavi ve takibinde önemli bir yer tutabilir. Anahtar kelimeler: Şizofreni, sigara içme, umutsuzluk, intihar, psikopatoloji
Address reprint requests to: Psychiatrist Okan Ekinci, Yozgat State Hospital, Department of Psychiatry, Yozgat - Turkey

Phone: +90-354-212-1070

Fax: +90-354-212-1071

E-mail address: drokanekinci@yahoo.com

Date of receipt: January 16, 2012

Date of acceptance:

April 16, 2012 


\section{INTRODUCTION}

$\mathrm{Ine}_{\mathrm{ne}}^{\mathrm{tin}}$ is already known that patients with schizophrenia not only have higher prevalence of cigarette smoking than healthy people but than people with other mental disorders as well. Cigarette smoking prevalence has been reported to be as high as $85-90 \%$ in cases with schizophrenia (1-3). Maintenance of neuro-regulator effects of nicotine is the most important factor of continuing cigarette smoking once started. Despite reinforcing and pleasure-giving effects of nicotine, rapid recovery of disturbing withdrawal symptoms is another factor. Reason of high prevalence of cigarette smoking in schizophrenia is uncertain. However, the most mentioned theory is "self-medication". This theory proposes that cases with schizophrenia smoke cigarette in order to reduce severity of positive and negative symptoms and improve cognitive functions. Improvement of selective attention and neuropsychological impairment in patients with schizophrenia after cigarette smoking in some studies supports this theory (4-6). Schizophrenia is related with dopaminergic activity increased at mesolimbic system (positive symptoms) and reduced at prefrontal region (negative symptoms).Thus, cigarette smoking has been proposed to reduce severity of negative symptoms and improve cognitive functions by temporarily increasing dopaminergic activity in prefrontal-subcortical network in schizophrenia. On the other hand, it is possible for patients with schizophrenia to smoke cigarette in order to reduce side effects of antipsychotic medications. Cigarette smoking has been suggested to improve extrapyramidal and cognitive side effects of antipsychotics by both decreasing blood levels of medications and increasing dopaminergic activity $(7,8)$. Some studies suggest that cigarette smoking reduces both physical adverse effects such as akathisia cognitive side effects such as memory and attention deficits of typical antipsychotics. This dopaminergic theory seems to be reasonable when lower cigarette smoking prevalence observed by clozapine which has a lower dopaminergic receptor occupation rate $(6,9)$.

Correlation between cigarette smoking and positive and negative symptoms, neuropsychological functions and adverse effects of medications has already been well-known. A correlation between suicide and impulsivity has also been mentioned in some studies $(6,10)$. There are a few studies in Turkey that investigated the relationship between cigarette smoking and psychopathology, socio-demographic characteristics and biological variables (11-13). On the other hand, it can be noted that few studies exist in the literature evaluating the relationship between cigarette smoking in schizophrenia and symptoms and signs, insight, impulsivity, suicide, depression and hopelessness comprehensively (14). For this reason, we aimed to determine the correlation between cigarette smoking and psychopathological violence, insight, impulsivity, depression and hopelessness, obsessive-compulsive symptoms, suicide and some socio-demographic characteristics in cases with schizophrenia. We assumed that cigarette smoking in schizophrenia will be significantly correlated with positive and negative symptoms; cases smoking cigarette will have higher impulsivity; and depression levels and history of suicide and violent behavior related with impulsivity will be more frequent in cases smoking cigarette. Moreover, we predicted that patients with schizophrenia will dissociate for socio-demographic and clinical characteristics as well.

\section{METHODS}

\section{Sample}

One hundred and thirty-three patients diagnosed schizophrenia according to DSM-IV diagnostic criteria that were being followed-up and treated from outpatient unit between November 2010 and March 2011 were included in this study (15). All patients included in the study were at stable period of disease. Patients were accepted at stable period if they did not experience an increase at severity of positive symptoms in previous six months, no hospital admission was required and no evident adjustment of antipsychotic medications were required in previous six months. Patients at acute psychotic exacerbation period, with mental retardation and having less than 23 points from Mini Mental State 
Examination were not included in the study. Patients with organic brain diseases such as brain tumor, epilepsy, systemic diseases, head trauma and/or surgery were also not included. Study was conducted with 133 patients because 7 patients or their families out of 140 who were initially met inclusion criteria refused to participate. Study was approved by local ethical committee, patients and their relatives were informed and volunteer patients were included in the study by informed consent documentation.

Cigarette smoking was determined by asking patients and their relatives -and if present- its duration and intensity. Cases who were smoking 20 cigarettes per day for at least one year were defined as nicotine addicts and made up our cigarette smoker group.

\section{Scales and Forms used in The Study}

\section{Socio-Demographic Data Form}

This form consisted of items about sociodemographic characteristics, family history, age of onset of disease, duration of disease, number of hospital admissions, suicidal attempts and violent behavior towards others and/or objects. First-degree relatives as well as health personnel involved in follow-up and treatment process of patient previously when sociodemographic and clinical characteristics were being interviewed.

\section{Structured Clinical Interview Scale for} DSM-IV Axis I Diagnoses (SCID-I): This is a structured clinical interview developed by First et al. (16) in 1997 fro DSM-IV Axis I disorders. SCID-I was developed to ease searching for DSM-IV diagnostic criteria, to increase validity of diagnoses and systematic search of symptoms by providing implementation of diagnostic evaluation in a standard manner. SCID-I determines presence of axis I diagnosis at any given time (lifetime prevalence) and presence or absence of impairment symptoms in the previous month $(16,17)$.

\section{Scale for the Assessment of Positive Symptoms} (SAPS): This scale was developed to assess level, distribution and severity of positive symptoms of schizophrenia. Validity and reliability study of Turkish form was done. Scores between 0 and 5 is given to each item $(18,19)$. It consists of five sub-scales which are hallucinations, delusions, bizarre behavior, positive formal thought disorder and inappropriate mood.

\section{Scale for the Assessment of Negative} Symptoms (SANS): This scale was developed to assess level, distribution and severity of negative symptoms of schizophrenia. Validity and reliability study of Turkish form was done. It consists of 5 subscale and 25 items. Scores between 0 and 5 is given to each item $(20,21)$. It consists of five sub-scales which are affective flattening and blunting, alogia, avolitionapathy, anhedonia-asociality and attention deficit.

\section{Calgary Depression Scale for Schizophrenia} (CDSS): CDSS is a scale developed by Addington et al. (22) to assess severity of depression in schizophrenia. Validity and reliability study of this scale in Turkish was done by Aydemir et al. (23). Cut-off score for schizophrenia accompanied by depressive disorder of Turkish version of CDSS was determined as 11/12.

Beck Cognitive Insight Scale (BCIS): This scale is a self-rated questionnaire consisting of 15 items developed to assess how individuals assess their own judgments. Each item is scored between 0 and 3. Two factors were obtained from previous studies: selfreflection and self-confidence. Self-reflection means tendency to accept alternative explanations, recognizing non-functional deductions, self-confidence means believing in him/herself about accuracy of current beliefs and judgments. Composite index is obtained by subtracting self-confidence score from self-reflection score. Turkish validity and reliability study was done $(24,25)$.

Scale to Assess Unawareness of Mental Disorder (SAUMD): This is a scale to assess clinical insight and examine insight by three sub-factors. It is rated by clinician. Three insight areas which are unawareness of presence of mental disorder, 
unawareness of social consequences of mental disorder and unawareness of treatment effectiveness are evaluated. Each item is scored between 1 and 5. Higher scores indicate worse clinical insight (26).

Yale-Brown Obsession-Compulsion Scale (YOCS): This scale was developed by Goodman et al. (27) to assess type and severity of obsessive-compulsive symptoms. It is administered by interviewer. Turkish adaptation and validity and reliability study was done by Karamustafalıoğlu et al. (28).

Barratt Impulsiveness Scale (BIS): This is a selfrating scale consisted of 30 items and developed to assess impulsivity. Individual is required to select the most appropriate one among "rarely/never", "occasionally", "often", "almostalways/always" options. Three sub-factors were obtained by factor analysis: a) Attention-related impulsiveness, b) Motor impulsiveness, c) Unintended impulsiveness. Attentionrelated impulsiveness represent intolerance to cognitive incoherence and impatience, motor impulsiveness represents getting into action without thinking on and unintended impulsiveness represents absence of future sensation. Higher scores indicate higher level of impulsiveness. Turkish validity and reliability study was done $(29,30)$.

Beck Hopelessness Scale (BHS): This scale was developed by Beck et al. (31) Its validity and reliability study was done by Seber et al.(32) and used to determine negative expectancies of individual towards future. BHS consists of 20 items and scored as 0 or 1 . Higher scores indicate higher level of hopelessness $(31,32)$.

\section{Statistical Analysis}

Validity of data from assessments to normal distribution was examined by Kolmogorov Smirnov test in statistical analyses. For comparison of assessed data of two groups (smoking or non-smoking patients with schizophrenia), Student's t test was used for normal distribution and Mann Whitney $U$ test for nonnormal distribution. Chi-square test was used to compare qualitative data. Data from assessments were shown as arithmetical mean \pm standard deviation and data obtained by counting were shown as percent value (\%). Age and gender were included into analysis when

Table 1: Socio-demographic and Clinical Characteristics

\begin{tabular}{|c|c|c|c|c|}
\hline & Smoking (-) n=44 & Smoking (+) n=89 & Statistical Analysis & $\mathbf{p}$ \\
\hline \multicolumn{5}{|l|}{ Demographic Characteristics } \\
\hline Age & $37.5 \pm 10.9$ & $35.9 \pm 9.5$ & $\mathrm{t}=0.81, \mathrm{df}=131$ & 0.42 \\
\hline \multicolumn{5}{|l|}{ Gender } \\
\hline Woman & $19(\% 43.2)$ & $26(\% 29.2)$ & \multirow{2}{*}{$\chi^{2}=2.56, \mathrm{df}=1$} & \multirow{2}{*}{0.11} \\
\hline Man & $25(\% 56.8)$ & $63(\% 70.8)$ & & \\
\hline Duration of Education (year) & $7.3 \pm 2.9$ & $7.4 \pm 3.7$ & $\mathrm{t}=-0.06, \mathrm{df}=131$ & 0.93 \\
\hline \multicolumn{5}{|l|}{ Marital Status } \\
\hline Single & $32(\% 72.7)$ & $61(\% 68.5)$ & \multirow{3}{*}{$\chi^{2}=0.467, \mathrm{df}=2$} & \multirow{3}{*}{0.79} \\
\hline Married & $7(\% 15.9)$ & $14(\% 14.7)$ & & \\
\hline Divorced/Widow & $5(\% 11.4)$ & $14(\% 14.7)$ & & \\
\hline \multicolumn{5}{|l|}{ Professional Status } \\
\hline Housewife & $16(\% 36.4)$ & $17(\% 19.1)$ & \multirow{3}{*}{$\chi^{2}=13.35, \mathrm{df}=4$} & \multirow{3}{*}{$0.01^{*}$} \\
\hline Unemployed & $14(\% 31.8)$ & $52(\% 51.4)$ & & \\
\hline Other & $14(\% 31.8)$ & $20(\% 29.5)$ & & \\
\hline \multicolumn{5}{|l|}{ Urban Status } \\
\hline Village & $10(\% 22.7)$ & $26(\% 29.2)$ & \multirow{3}{*}{$\chi^{2}=1.12, \mathrm{df}=2$} & \multirow{3}{*}{0.56} \\
\hline Town & $7(\% 15.9)$ & $17(\% 19.1)$ & & \\
\hline City & $27(\% 61.4)$ & $46(\% 51.7)$ & & \\
\hline \multicolumn{5}{|l|}{ Socioeconomic Level } \\
\hline Low & $21(\% 47.7)$ & $55(\% 61.8)$ & \multirow{3}{*}{$\chi^{2}=4.9, \mathrm{df}=3$} & \multirow{3}{*}{0.17} \\
\hline Moderate & $21(\% 47.7)$ & $26(\% 29.2)$ & & \\
\hline High & $2(\% 4.6)$ & $8(\% 8.9)$ & & \\
\hline
\end{tabular}

${ }^{*} \mathrm{p}<0.05, \chi^{2}=$ Chi-square test, $\mathrm{t}=$ Student's $\mathrm{t}$ test, $\mathrm{df}=$ Degree of freedom 
psychopathological variables were being compared and severity of positive and negative symptoms, age, gender and duration of education were included as co-variables when comparisons related with insight were being done and ANCOVA test was used for comparison. Level of significance was taken as $p<0.05$.

\section{RESULTS}

$66.9 \%$ of the sample was smoking over 20 cigarettes daily for over one year and met nicotine dependence diagnostic criteria according to DSM-IV. Sociodemographic and clinical characteristics of patients are shown at table 1 . No significant difference was found between smoking and non-smoking patients according to age, gender, marital status, socio-economic status and duration for education. Unemployment rate was significantly higher in smoking patients than nonsmoking ones.

No significant difference was found between groups regarding age of onset of disease and disease duration. On the other hand, smokers were found to have higher prevalence of suicidal attempt than non-smokers. Only $2.3 \%$ of non-smokers attempted suicide previously but this rate was $37.2 \%$ for smokers. Significant difference was found between two groups regarding hospital admissions. Smokers were found to be treated as inpatients more. Smokers were also found to have more

Table 2: Comparison of clinical characteristics and psychopathological variables in smoking and non-smoking cases

\begin{tabular}{|c|c|c|c|c|}
\hline & Smoking (-) $n=44$ & Smoking (+) n=89 & Statistical Analysis & $\mathbf{p}$ \\
\hline \multicolumn{5}{|l|}{ CLINICAL CHARACTERISTICS } \\
\hline Age of Onset & $22.6 \pm 7.2$ & $23.7 \pm 7.4$ & $\mathrm{t}=-0.82, \mathrm{df}=131$ & 0.41 \\
\hline Duration of Disease & $15.0 \pm 10.2$ & $12.2 \pm 8.2$ & $t=1.66, d f=131$ & 0.09 \\
\hline Number of Admissions & $1.6 \pm 1.2$ & $2.6 \pm 2.8$ & $\mathrm{t}=-1.99, \mathrm{df}=131$ & $0.04^{*}$ \\
\hline Alcohol-substance abuse & $3(\% 6.8)$ & $20(\% 23)$ & $\chi^{2}=4.21, \mathrm{df}=1$ & $0.04^{*}$ \\
\hline Family History of Psychiatric Disease & $29(\% 65.9)$ & $59(\% 66.3)$ & $\chi^{2}=0.01, \mathrm{df}=1$ & 0.96 \\
\hline History of Suicidal Attempt & $1(\% 2.3)$ & $33(\% 37.1)$ & $\chi^{2}=21.69, \mathrm{df}=1$ & $<0.001^{* *}$ \\
\hline Violent Behavior & $12(\% 70.8)$ & $26(\% 29.2)$ & $\chi^{2}=0.05, \mathrm{df}=1$ & 0.81 \\
\hline \multicolumn{5}{|l|}{ PSYCHOPATHOLOGICAL VARIABLES } \\
\hline Total Score of Positive Symptoms & $24.8 \pm 16.4$ & $34.7 \pm 16.5$ & $\mathrm{~F}=9.51$ & $0.001^{*}$ \\
\hline Hallucinations & $6.8 \pm 5.1$ & $9.3 \pm 4.2$ & $\mathrm{t}=0.526$ & 0.06 \\
\hline Delusions & $11.7 \pm 9.8$ & $13.8 \pm 7.6$ & $\mathrm{t}=-0.045$ & 0.09 \\
\hline Bizarre Behavior & $4.2 \pm 3.4$ & $6.3 \pm 2.4$ & $\mathrm{t}=-0.348$ & 0.07 \\
\hline Positive Formal Thought Disorder & $1.5 \pm 1.5$ & $3.4 \pm 1.2$ & $\mathrm{t}=0.523$ & 0.06 \\
\hline Inappropriate Affect & $1.7 \pm 1.8$ & $1.9 \pm 1.1$ & $\mathrm{t}=-0.731$ & 0.46 \\
\hline Total Score of Negative Symptoms & $31.7 \pm 17.4$ & $41.1 \pm 15.3$ & $\mathrm{~F}=8.16$ & $0.002^{*}$ \\
\hline Affective Flattening or Blunting & $7.6 \pm 5.7$ & $8.8 \pm 4.1$ & $\mathrm{t}=0.567$ & 0.06 \\
\hline Alogia & $5.6 \pm 3.1$ & $6.9 \pm 3.3$ & $t=0.163$ & 0.09 \\
\hline Avolition/Apathy & $6.2 \pm 4.1$ & $7.6 \pm 3.6$ & $\mathrm{t}=0.245$ & 0.80 \\
\hline Anhedonia/Asociality & $7.7 \pm 4.5$ & $7.9 \pm 2.4$ & $\mathrm{t}=-0.348$ & 0.72 \\
\hline Attention Deficit & $4.5 \pm 2.1$ & $5.8 \pm 2.3$ & $\mathrm{t}=-0.204$ & 0.08 \\
\hline Calgary Depression Scale (CDS) & $2.9 \pm 3.8$ & $4.1 \pm 4.3$ & $\mathrm{~F}=1.22$ & 0.27 \\
\hline Beck Hopelessness Scale & $6.9 \pm 3.7$ & $9.1 \pm 4.9$ & $\mathrm{~F}=7.41$ & $<0.01^{*}$ \\
\hline $\begin{array}{l}\text { Yale-Brown Obsession-Compulsion Scale } \\
\text { (Y-BCOS) }\end{array}$ & $5.1 \pm 9.2$ & $5.3 \pm 10.1$ & $\mathrm{~F}=0.02$ & 0.91 \\
\hline Barratt Impulsiveness Scale (BIS) & $62.1 \pm 10.5$ & $68.3 \pm 10.4$ & $\mathrm{~F}=5.21$ & $0.01^{*}$ \\
\hline Nonplanning-BIS & $23.6 \pm 4.2$ & $24.1 \pm 3.7$ & $\mathrm{~F}=1.25$ & 0.22 \\
\hline Attentional-BIS & $14.4 \pm 3.5$ & $18.4 \pm 4.1$ & $\mathrm{~F}=3.61$ & $0.04^{*}$ \\
\hline Motor-BIS & $25.1 \pm 3.8$ & $25.2 \pm 3.4$ & $\mathrm{~F}=1.60$ & 0.07 \\
\hline
\end{tabular}

${ }^{*} \mathrm{p}<0.05,{ }^{* *} \mathrm{p}<0.001, \chi^{2}=$ Chi-square test, $\mathrm{t}=$ Student's $\mathrm{t}$ test, $\mathrm{F}=$ One-way analysis of variance, $\mathrm{df}=$ Degree of freedom 
Table 3: Comparison of components of insight in smoking and non-smoking cases

\begin{tabular}{|c|c|c|c|c|}
\hline & Smoking (-) $n=44$ & Smoking (+) $\mathrm{n}=89$ & ANCOVA & $\mathbf{p}$ \\
\hline \multicolumn{5}{|l|}{ Lack of Insight to Mental Disease Scale } \\
\hline Total lack of insight & $7.7 \pm 4.4$ & $8.2 \pm 3.7$ & $\mathrm{~F}=0.754$ & 0.387 \\
\hline Lack of insight to presence of mental disease (LIMDS1) & $2.7 \pm 1.6$ & $2.9 \pm 1.5$ & $\mathrm{~F}=1.133$ & 0.289 \\
\hline Lack of insight to social consequences (LIMDS2) & $2.5 \pm 1.6$ & $2.7 \pm 1.4$ & $\mathrm{~F}=0.955$ & 0.330 \\
\hline Lack of insight to treatment efficacy (LIMDS3) & $2.5 \pm 1.4$ & $2.6 \pm 1.3$ & $\mathrm{~F}=0.034$ & 0.853 \\
\hline \multicolumn{5}{|l|}{ Beck Cognitive Insight Scale } \\
\hline Composite index & $2.4 \pm 5.2$ & $2.3 \pm 5.2$ & $\mathrm{~F}=0.144$ & 0.705 \\
\hline Self-reflection & $11.7 \pm 4.5$ & $12.0 \pm 4.8$ & $\mathrm{~F}=0.001$ & 0.976 \\
\hline Self-confidence & $9.3 \pm 2.6$ & $9.7 \pm 3.6$ & $\mathrm{~F}=0.413$ & 0.522 \\
\hline
\end{tabular}

F=One-way analysis of covariance (ANCOVA)

ANCOVA (age, gender and severity of positive and negative symptoms were included as co-variables).

frequent alcohol-substance abuse. No significant difference was found between two groups regarding family history of psychiatric disease and history of violent behavior (Table 2).

Two groups were compared for psychopathological variables as well. Smokers were found to have significantly higher total SAPS and SANS scores. On the other hand, severity of hopelessness was found to be higher in smokers than non-smokers. When groups were compared according to impulsiveness, smokers were found to have significantly higher total impulsiveness and attention-related impulsiveness scores. However, no significant difference was found between two groups regarding positive and negative symptom sub-scale scores, obsessive-compulsive symptoms and severity of depression (Table 2).

When two groups were compared according to insight and cognitive insight scores, no significant difference was found between smoking and nonsmoking cases with schizophrenia regarding total and sub-scale insight scores and also cognitive insight and sub-scale scores (Table 3).

\section{DISCUSSION}

To our knowledge, our study is the first study done in Turkey comparing smoking and non-smoking cases with schizophrenia regarding socio-demographic and clinical characteristics, severity of positive and negative symptoms, level of impulsiveness, severity of obsessivecompulsive symptoms, components of insight, hopelessness and severity of depression. Findings of our study indicate that positive and negative symptoms, impulsiveness and hopelessness levels are more severe and hospital admissions, suicidal attempts and unemployment are more frequent in smoking cases with schizophrenia. Prevalence of smoking was found $67 \%$ in our sample. This finding seems to be lower than previous studies which reported rates as high as $85-95 \%$ (6). This difference might have been due factors different from previous studies such as sample size of our study, socio-cultural characteristics and definition of smoking. Smoking rate in cases with schizophrenia reported as $72 \%$ from a study done in Turkey is similar to our finding and suggests the importance of socio-cultural differences (11). Other studies from Turkey reported rates of $45 \%$ and $50 \%(13,33)$. Differences in smoking rates were also reported to be related with variables such as types and doses of antipsychotics used and additional anticholinergic use (2).

After adjusting age, gender and educational level, more severe positive and negative symptoms in smoking cases in our study and higher number of hospital admissions indicate a more severe disease course in these cases. Previous studies also support this finding. Presence of smoking has been reported to be cause or consequence of a more severe psychopathology. This severity has also been proposed to be due to additional substance abuse of cases who are smoking. According to this hypothesis, additional substance abuse increases severity of psychopathology and hospital admissions. Higher prevalence of alcohol-substance abuse among smoking cases in our study support this hypothesis $(6,34,35)$. Another hypothesis is patients with more 
severe psychopathology may be smoking to reduce adverse psychic (e.g., anhedonia) and physical (i.e., Parkinsonism) effects secondary to these symptoms or higher medication doses. However, it can be proposed that smoking affects severity of psychopathology regardless of its cause. Another point of view is that severity of psychopathology affects smoking rates. There was no significant difference between negative and positive symptoms regarding symptom sub-types. This finding of our study supports previous studies proposing no relationship between symptom sub-types and smoking (36-38).

On the other hand, no difference was found between smoking and non-smoking cases regarding clinical and insight components. Lack of insight might have been expected to increase smoking by increasing psychopathology or better insight might have been expected to enhance depression and thus increase smoking. However, our findings do not support both hypotheses and lack of studies investigating relationship between smoking and insightin cases with schizophrenia makes it difficult to interpret. Future studies in wider sample groups and in longitudinal fashion may reveal the relationship between these two entities.

Another interesting finding of our study is higher prevalence of suicidal attempts in smoking cases with schizophrenia. Relationship between smoking and suicidal attempts in schizophrenia was emphasized in previous studies and smoking was proposed to increase suicidal tendency by enhancing psychopathology underlying suicidal attempt. Some studies reported that smoking increases frequency of suicidal attempts by increasing impulsiveness $(10,39)$. Higher prevalence of hopelessness in smoking cases which is an important predictor of suicidal attempts in cases with mood disorders in ourstudy also supports the close relationship between smoking and suicidal attempts. In other words, patients with schizophrenia may be smoking to cope with hopelessness, pessimism and stress. Moreover, they may attempt suicide in consequence of frustration when they do not cope with these undesired feelings. According to these findings, level of hopelessness in patients with schizophrenia should be monitored closely, additional interventions should be performed to help patients cope with these undesired feelings and patients should be monitored more closely regarding suicidal attempts (40).

Higher total and attention-related impulsiveness levels were found in smoking cases in our study. This finding is consistent with previous studies. However, whether impulsiveness is cause or consequence of smoking cannot be concluded due to design of our study. Longitudinal follow-up studies are needed to understand this issue $(41,42)$. However, attentionrelated and total impulsiveness scores during recovery periods were found to be important predictors of previous suicidal attempts in bipolar and major depressive cases. Significantly higher prevalence of suicidal attempts in smoking cases in our study suggests that smoking cases with schizophrenia is due to higher impulsiveness levels. Individuals with higher attentionrelated impulsiveness levels lack complex thinking abilities and thought elasticity so they cannot consider long-term consequences of an action $(43,44)$. From this perspective, high level of attention-related impulsiveness may trigger smoking and concomitant suicidal attempt which have long-term consequences. This may clinically have two meanings: first, smoking cases with schizophrenia should be evaluated for impulsiveness; second, cases with comorbid impulsiveness and smoking should be better monitored for suicidal attempts.

It cannot be undervalued that our study has some limitations. First, our sample is small and our study has a cross-sectional design. So cause-consequence correlation cannot be created with our findings. Future studies should test the correlation between smoking and clinical characteristics longitudinally. Besides, our study sample consists of outpatients only and cannot represent all patients with schizophrenia. Most of the scale used are self-scales and this may reduce reliability of our results. Detecting nicotine dependence with more specific methods than DSM-IV such as Fagerstrom test might have increased reliability of findings. Moreover, it might have been significant to evaluate neurocognitive functions with other variables because of well-known effects of nicotine on cognitive functions. 


\section{CONCLUSION}

Findings of our study indicate a substantially high prevalence of smoking in schizophrenia. Our study supports the close relationship between smoking and severity of psychopathology in schizophrenia which was reported previously. Furthermore, it indicates a correlation between smoking and suicidal attempts, hopelessness and impulsiveness. Correlation between smoking and suicidal attempts, hopelessness and impulsiveness in cases with schizophrenia may have an

\section{REFERENCES}

1. De Leon J, Dadvand M, Canuso C, White AO, Stanilla JK, Simpson GM. Schizophrenia and smoking: an epidemiological survey in a state hospital. Am J Psychiatry 1995; 152:453-455.

2. Etter M, Mohr S, Garin C, Etter JF. Stages of change in smokers with schizophrenia or schizoaffective disorder and in the general population. Schizophr Bull 2004; 30:359-368.

3. De Leon J, Diaz F. A meta-analysis of worldwide studies demonstrates an association between schizophrenia and tobacco smoking behaviors. Schizophr Res 2005; 76:135-157.

4. Berlin I, Singleton EG, Pedarriosse AM, Lancrenon S, Rames A, Aubin HJ, Niaura R. The modified reasons for smoking scale: factorial structure, gender effects and relationship with nicotine dependence and smoking cessation in French smokers. Addiction 2003; 98:1575-1583.

5. Ziedonis DM, Kosten TR, Glazer WM, Frances RJ. Nicotine dependence and schizophrenia. Hosp Community Psychiatry 1994; 45:204-206.

6. Lyon ER. A review of the effects of nicotine on schizophrenia and antipsychotic medications. Psychiatr Serv 1999; 50:13461350.

7. Nomikos GG, Schilstorm B, Hildebrand BE, Panagis G, Grenhoff J, Svensson TH. Role of alpha 7 nicotine receptors in nicotine dependence and implications for psychiatric illness. Behav Brain Res 2000; 113:97-113.

8. Kumari V, Postma P. Nicotine use in schizophrenia: the self medication hypotheses. Neurosci Biobehav Rev 2005; 29:10211034.

9. Barnes M, Lawford BR, Burton SC, Heslop KR, Noble EP, Hausdorf K, Young RM. Smoking and schizophrenia: is symptoms profile related to smoking and which antipsychotic medication is of benefit in reducing cigarette use? Aust N Z J Psychiatry 2006; 40:575-580. important role in treatment and follow-up of this patient group. However, it is clear that longitudinal studies are needed to better understand relationship between smoking and psychopathology. Clinicians should consider relationship between smoking and suicidal attempts, impulsiveness and other psychopathological features when during follow-up of patients with schizophrenia. Moreover, when its relationship with severity of disease is considered, quitting programs which are more difficult processes should attract more attention in this patient group.

10. Iancu I, Sapir AP, Sbaked G, Poreb A, Dannon PN, Cbelben J, Kotler M. Increased suicidal risk among smoking schizophrenia patients. Clin Neuropharmacol 2006; 29:230-237.

11. Karşıdag C, Alpay N, Kocabıyık A. Şizofreni ve sigara bağımlılığı. Düşünen Adam: Psikiyatri ve Nörolojik Bilimler Dergisi 2005; 18:13-20 (Article in Turkish).

12. Turan T, Dolu N, Ozsoy S, Kilıc C, Beşirli A, Esel E. Effects of smoking on P50 waveform in schizophrenic patients. Klinik Psikofarmakoloji Bülteni 2009; 19:226-234.

13. Uzun Ö, Cansever A, Basoğlu B. Smoking and substance abuse in outpatients with schizophrenia: a 2-year follow-up study in Turkey. Drug Alcohol Depend 2003; 70:187-192.

14. Kao YC, Liu YP, Cheng TH, Chou MK. Cigarette smoking in outpatients with chronic schizophrenia in Taiwan: relationships to socio-demographic and clinical characteristics. Psychiatry Res 2011; 190:193-199.

15. American Psychiatric Association. Diagnostic and Statistical Manual of Mental Disorders. Fourth Ed. Author, Washington, DC, 2000.

16. First MB, Spitzer RL, Gibbon M. Structured Clinical Interview for DSM-IVAxis I Disorders (SCID) Clinician Version. American Psychiatric Press, Washington, DC., 1996.

17. Corapcioglu A, Aydemir O, Yildiz M. Structured Clinical Interview for DSM-IV (SCID-IV), Turkish Version (Turkish). Hekimler Yayin Birligi, Ankara, Turkey, 1999 (Article in Turkish).

18. Andreasen NC. Scale for the Assessment of Positive Symptoms (SAPS). College of Medicine, University of Iowa, Iowa City, 1984.

19. Erkoç S, Arkonaç O, Atakli C. Pozitif semptomları değerlendirme ölçeğinin güvenilirliği ve geçerliliği. Düşünen Adam: Psikiyatri ve Nörolojik Bilimler Dergisi 1991; 4:20-24 (Article in Turkish). 
20. Andreasen NC. Scale for the assessment of negative symptoms (sans). College of Medicine, University of Iowa, Iowa City, 1984.

21. Erkoç S, Arkonaç $O$, Atakli C. Negatif semptomları değerlendirme ölçeğinin güvenilirliği ve geçerliliği. Düşünen Adam: Psikiyatri ve Nörolojik Bilimler Dergisi 1991; 4:14-15 (Article in Turkish).

22. Addington D, Addinton J, Maticka-Tyndale E, Joyce J. Reliability and validity of a depression rating scale for schizophrenics. Schizophr Res 1992; 6:201-208.

23. Aydemir Ö, Esen A, Deveci A. Calgary Şizofrenide Depresyon Ölçeği'nin Türkçe versiyonunun güvenilirliği ve geçerliliği. Nöropsikiyatri Arsivi 2000; 37:82-86 (Article in Turkish).

24. Beck AT, Baruch E, Balter JM, Steer RA, Warman DM. A new instrument for measuring insight: The Beck cognitive insight scale. Schizophr Res 2004; 68:319-329.

25. Aslan S, Turkcapar H, Güney E, Eren N, Akkoca Y, Ugurlu M. Beck Bilişsel çgörü Ölçeği Türkçe Formu'nun şizofrenik hastalar için güvenilirlik ve geçerlilik çalışması. Klinik Psikiyatri Dergisi 2005; 8:186-196 (Article in Turkish).

26. Amador XF, Strauss DH, Yale SA, Flaum MM, Endicott J, Gorman JM. Assessment of insight in psychosis. Am J Psychiatry 1993; 150:873-879.

27. Goodman WK, Price LH, Rasmussen SA. The Yale-Brown obsessive compulsive scale, I: development, use and reliability. Arch Gen Psychiatry 1989; 46:1006-11.

28. Karamustafalığlu O, Üçok AM, Ulusoy M, Erkmen H. YaleBrown obsesyon-kompulsiyon derecelendirme ölçeğinin geçerlilik ve güvenirlik çalışması. National Psychiatry Congress, 1993 (Article in Turkish).

29. Patton JH, Stanford MS, Barratt ES. Factor structure of the Barratt impulsiveness scale. J Clin Psychol 1995; 51:768-774.

30. Hıdıroğlu C. Bipolar bozukluk tanılı ötimik hastalar ve birinci derece akrabalarında dürtüsellik: Sağliklı kontrollerle karşılaştırmalı bir çalışma. Dokuz Eylül Üniversitesi · Sağlık Bilimleri Enstitüsü, Uzmanlık Tezi, İzmir, 2009 (Thesis in Turkish).

31. Beck AT, Weissman A, Lester D, Trexler L. The measurement of pessimism: The Hopelessness Scale. J Consult Clin Psychol 1974; 42:861-865.

32. Seber G, Dilbaz N, Kaptanoğlu C, Tekin D. Umutsuzluk Ölçeği: Geçerlilik ve güvenirlilik çalışması. Kriz Dergisi 1993;1:139-142 (Article in Turkish).
33. Yıldız M, Özcan ME. Ayaktan izlenen psikiyatri hastalarında nikotin bağımlılı̆̆ı yaygınlığı. Bağımlılık Dergisi 2000; 1:86-88 (Article in Turkish).

34. Goff DC, Henderson DC, Amico E. Cigarette smoking in schizophrenia: relationship to psychopathology and medication side effects. Am J Psychiatry 1992; 149:1189-1194.

35. Patkar AA, Gopalakrishnan R, Lundy A, Leone FT, Certa KM, Weistein SP. Relationship between smoking and positive and negative symptoms in schizophrenia. J Nerv Ment Dis 2002;190:604-610.

36. Barnes M, Lawford BR, Burton SC. Smoking and schizophrenia: is symptom profile related to smoking and which antipsychotic medication is of benefit in reducing cigarette use? Aust N Z J Psychiatry 2006; 40:575-580.

37. Herran A, de Santiago A, Sandoya M. Determinants of smoking behavior in outpatients with schizophrenia. Schizophr Res 2000; 41:373-381.

38. Liao DL, Yang JY, Lee SM, Chen H, Tsai SJ. Smoking in chronic schizophrenic inpatients in Taiwan. Neuropsychobiology 2002; 42:172-175.

39. Beratis S, Katrivanou A, Gourzis P. Factors affecting smoking in schizophrenia. Compr Psychiatry 2001; 42:393-402.

40. Miller M, Hemenway D, Bel NS, Yore MM, Amoroso PJ. Cigarette smoking and suicide: a prospective study of 300.000 male active-duty army soldiers. Am J Epidemiol 2000; 151:1060 1063.

41. Hull-Blank EE, Kerr BA, Robison-Kurpius SE. Risk factors of suicidal ideations and attempts in talented, at-risk girls. Suicide Life Threat Behav 2004; 34:267-276.

42. Yen S, Shea MT, Sanislow CA, Grilo CM, Skodol AE, Gunderson JG, McGlashan TH, Zanarini MC, Morey LC. Borderline personality disorder criteria associated with prospectively observed suicidal behavior. Am J Psychiatry 2004; 161:12961298.

43. Ekinci $O$, Albayrak Y, Ekinci AE, Caykoylu A. Relationship of trait impulsivity with clinical presentation in euthymic bipolar disorder patients. Psychiatry Res 2011; 190:259-264.

44. Ekinci O, Albayrak Y, Caykoylu A. Impulsivity in euthymic patients with major depressive disorder: the relation to sociodemographic and clinical properties. J Nerv Ment Dis 2011; 199:454-458. 